\title{
Også moderat hjerneskade kan gi men
}

\author{
Pasienter med moderate traumatiske hjerneskader bør følges opp \\ bedre, både rett etter skaden og på lang sikt. Mange sliter med dårlig \\ helse ett år etter skaden, og etter ti år er 30 \% uføre.
}

Nada Hadzic-Andelic har undersøkt forekomsten av akutte traumatiske hjerneskader i Oslo (se ordforklaringer), og også studert funksjonsutfall og helserelatert livskvalitet blant voksne i alderen 16-55 år, alle med moderat til alvorlig traumatisk hjerneskade.

- Pasientene, også flere av dem med mindre alvorlige skader, rapporterte om stor grad av uførhet og dårlig helse ett år etter hodeskaden. Hver fjerde pasient trengte

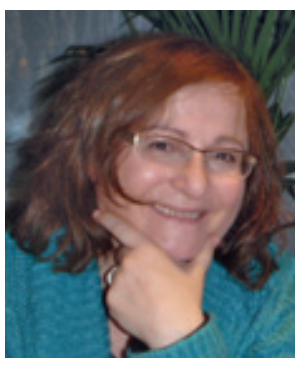

Nada Hadzic-Andelic. Foto privat aktiviteter, blant annet fordi de var blitt rotete og glemsomme. Etter ti år var de fleste pasientene i relativt god form, både fysisk og kognitivt, men hadde likevel nedsatt livskvalitet sammenhjelp til daglige liknet med den generelle befolkningen, sier Hadzic-Andelic.

Hun mener at også pasienter med mindre alvorlige hjerneskader bør få tilbud om strukturert rehabilitering etter utskrivning fra sykehus.

- For å identifisere problemer og sette i verk tiltak bør de følges opp bedre både i den subakutte fasen og på sikt. Det ville gitt flere pasienter bedre utfall ett år etter skaden, og flere av de som er uføre etter ti år kunne ha blitt rehabilitert, sier hun.

Hadzic-Andelic disputerte for ph.d.graden ved Universitetet i Oslo 19.4. 2010 med avhandlingen Moderate-to-severe traumatic brain injury in Eastern Norway: trends and challenges.

\section{Eline Feiring}

eline.feiring@legeforeningen.no

Tidsskriftet

\section{Ordforklaringer}

Akutt traumatisk hjerneskade: Ytre skade
mot hodet som forårsaker forandringer
i hjernen. Gir seg utslag i bevissthetstap,
hukommelsestap, ulike nevrologiske utfall og
strukturelle skader i hjernen. Akutt trauma-
tisk hjerneskade rammer ca. 10000 nord-
menn hvert år. Det er høyest forekomst blant
barn (0-4 år) og eldre lover 75 år), men også
høy forekomst blant yngre voksne (20-29 år).
Blant små barn og eldre er det fallulykker
som er hovedårsaken, blant yngre voksne
trafikkulykker, mens ungdom ( $10-14$ år) of-
test får hjerneskader i forbindelse med idrett test far hjerneskaderi forbindelse med idre

Moderat eller alvorlig? I den akutte fasen vurderes alvorlighetsgrad av traumatisk hjerneskade ut ifra pasientens bevissthetsnivå målt med Glasgow Coma Scale (GCS). GCS-skår $\leq 8$ indikerer alvorlig traumatisk hjerneskade (bevisstløs pasient), mens GCS-skår 9-12 lvåken pasient, fokale nevrologiske utfall) indikerer moderat traumatisk hjerneskade.

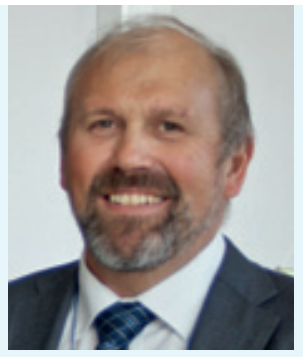

Torbjørn Øien. Foto privat

\author{
Barn som spiser fet fisk minst én gang i uken ved ett års alder har \\ betydelig lavere forekomst av eksem ved to års alder. Inntak av tran \\ har ikke denne effekten.
}

Forekomsten av allergiske sykdommer hos barn har økt de siste 30-40 årene - også i Norge. I 2000 startet forskere ved Norges teknisk-naturvitenskapelige universitet et intervensjonsprosjekt for å forebygge allergiske sykdommer hos barn. I avhandlingen Challenges in primary prevention of allergy. The prevention of allergy among children in Trondheim (PACT) study studerte Torbjørn Øien bl.a. om risikofaktorer for allergisk sykdom ble endret gjennom intervensjonstiltak.

PACT er en kontrollert prospektiv intervensjonsstudie. Intervensjonspakken besto av økt inntak av fet fisk og tran, redusert tobakkseksponering og redusert fukt i boligen under graviditeten og $\mathrm{i}$ barnas to første leveår.

- I intervensjonsgruppen var inntak av fet fisk og tran høyere enn i kontrollgruppen. Gravide i intervensjonsgruppen røykte mindre, men nedgangen var trolig et resultat av en tidstrend. De som ikke sluttet å røyke spontant, lot seg ikke påvirke av vår intervensjon. Tiltak mot fukt i boligen nådde ikke frem. Inntak av fisk og sammenhengen med eksem var tydelig: Fisk hadde en beskyttende effekt mot eksem - spesielt når ettåringen spiste fet fisk minst én gang $i$ uken. Inntak av tran viste ingen sammenheng med forekomsten av allergisk sykdom. Derfor tror vi at fet fisk må inneholde noen andre allergibeskyttende faktorer enn omega-3-fettsyrer, sier Øien.

Han disputerte for ph.d.-graden ved Norges teknisk-naturvitenskapelige universitet 9.4. 2010.

\section{Anne Forus}

anneforu@online.no

Tidsskriftet

\section{Ordforklaringer}

Allergiske sykdommer: I denne studien omfatter dette astma, eksem og høysnue.

PACT-studien: Intervensjonsstudie blant gravide kvinner og små barn. Studien var basert på selvrapportering hos to grupper. Deltakerne svarte på spørreskjema under svangerskapet, seks uker etter fødsel og da barna var ett og to år gamle. Gravide i intervensjonsgruppen skulle spise fet fisk minst to dager i uken og ta tran, og barna skulle få tran fra de var 4-6 uker og fet fisk fra seks måneders alder. Røykende gravide i intervensjonsgruppen fikk tilbud om strukturert røykeavvenning og råd om hvordan de kunne oppdage fukt i hjemmet og redusere risiko for fukt. Kontrollgruppen fikk samme type kostholdsveiledning, råd om røyking og inneklima som andre gravide og småbarnsforeldre ellers i landet. 